\title{
PERMODELAN DESAIN GEDUNG PERKULIAHAN FAKULTAS TEKNIK MENGGUNAKAN PROGRAM ETABS DAN LUMION PADA KAMPUS UNIVERSITAS SANG BUMI RUWA JURAI
}

\author{
Fery Hendi Jaya ${ }^{1}$, Farida Juwita ${ }^{2}$ Surya Agung DP ${ }^{3}$ \\ Universitas Sang Bumi Ruwa Jurai \\ feryhjaya@gmail.com ${ }^{1}$, ida.juwitaft@gmail.com ${ }^{2}$
}

\begin{abstract}
Abstrak
Kebutuhan gedung/tempat bagi proses belajar-mengajar di dunia akademik yakni kampus merupakan suatu yang tidak terpisahkan dan kebutuhan skunder dalam indikator keberhasilan dalam capaian proses akademik. Desain gedung kampus fakultas teknik universitas sang bumi ruwa jurai yang akan direncanakan ini , diharapkan dapat menjawab apa yang diinginkan oleh Yayasan Saburai sebagai pemilik kampus karena memenuhi ketentuan yakni ; kuat/kokoh, ekonomis, arsitektur modern tanpa menghilangkan karakteristik daerah, aman, nyaman dan layak fungsi. Hasil rancangan desain Gedung Fakultas Teknik yang terletak di kampus ini menggunakan program terbaru yakni Etabs yang berguna untuk perhitungan struktur kekuatan gedung dan program Lumion yang berguna untuk mendesain arsitektur (tataletak, warna, lampu, animasi,etc) gedung yang dapat dilihat dari berbagai sudut pandang (dimensi prespektif). Untuk perhitungan struktur mengacu pada SNI 1727:2013 dan PPIUG 1983 (Struktur Beton kolom, balok, pelat lantai/atap mengacu SNI-2847:2012), sedangkan pembebanan gempa mengacu pada SNI 1726:2012. Maka dihasilkan permodelan rancangan gedung dekanat dan perkuliahan untuk fakultas teknik universitas sang bumi ruwa jurai yang sangat inovasi sesuai dengan bidang ilmu yang dimiliki.
\end{abstract}

Kata Kunci: desain gedung, struktur gedung, etabs, lumion dan permodelan

\begin{abstract}
The need for a building / place for the teaching and learning process in the academic world, namely the campus is an inseparable and secondary need in indicators of success in the achievement of the academic process. The design of the campus building of the engineering faculty of the Earth Ruwa Jurai University that will be planned is expected to be able to answer what the Saburai Foundation wants as the campus owner because it meets the requirements, namely; strong / sturdy, economical, modern architecture without losing the characteristics of the area, safe, comfortable and worthy of function. The design results of the Faculty of Engineering building which is located on this campus use the latest program namely Etabs which is useful for calculating the strength structure of the building and the Lumion program which is useful for designing architecture (layout, colors, lights, animation, etc.) of buildings that can be seen from various points of view. (perspective dimension). For structural calculations, refer to SNI 1727: 2013 and PPIUG 1983 (Concrete structures for columns, beams, floor / roof plates refers to SNI-2847: 2012), while earthquake loading refers to SNI 1726: 2012. Then the resulting dean and lecture building design modeling for the engineering faculty of Sang Bumi Ruwa Jurai University which is very innovative in accordance with the field of science they have.
\end{abstract}

Keywords: building design, building structure, etabs, lumion and modeling

\section{PENDAHULUAN}

Universitas Sang Bumi Ruwa Jurai merupakan salah satu perguruan tinggi swasta di Bandar Lampung yang semakin berkembang. Mulai dari sumber daya manusianya yaitu dosen pengajar, karyawan dan mahasiswa, hingga sarana dan prasarana dilingkungan kampus. Namun dalam proses menuju perbaikan, tidak jarang dihadang berbagai hambatan dan kendala. 
Dalam perancangan struktur suatu bangunan gedung bertingkat ada banyak faktor yang harus diperhatikan, antara lain fungsi bangunan, keamanan, kekuatan (struktur), keindahan (arsitektural), kestabilan, serta pertimbangan ekonomis dan sosial. Struktur bangunan gedung secara umum dapat dibagi menjadi tiga bagian utama, yaitu struktur bawah, struktur tengah dan struktur atas. Struktur bawah adalah bagian-bagian bangunan yang terletak di bawah permukaan tanah (pondasi dan sloof). Struktur tengah merupakan bagian-bagian bangunan yang terletak di atas permukaan tanah dan di bawah atap (dinding, kolom, plat dan ring balk), Sedangkan struktur atas yaitu bagian-bagian bangunan yang terbentuk memanjang ke atas untuk menopang atap. Struktur atas bangunan antara lain rangka dan kuda-kuda. Dan yang tidak kalah penting yakni dapat memadukan seni, estetika dan kultur (arsitektur) pada rancangan gedung tersebut.

\section{METODE PENELITIAN}

Penelitian perencanaan gedung fakultas teknik ini dilaksanakan di kampus Universitas Sang Bumi Ruwa Jurai yang beralamat di Jalan Imam Bonjol No. 468 Langkapura Kota Bandar Lampung. Penelitian dilaksanakan dari bulan Juli sampai dengan bulan Oktober 2020.

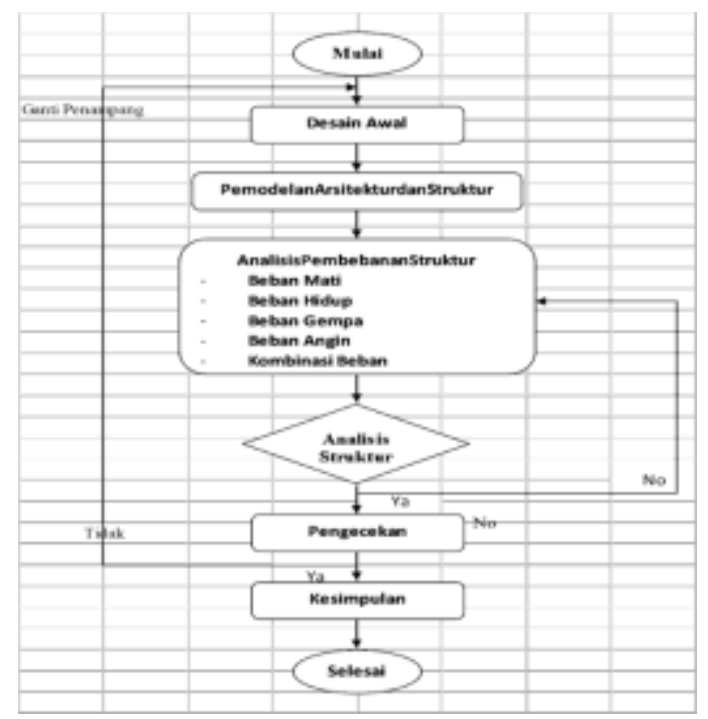

Gambar 1. Diagram Alir Penelitian

\section{HASIL DAN PEMBAHASAN}

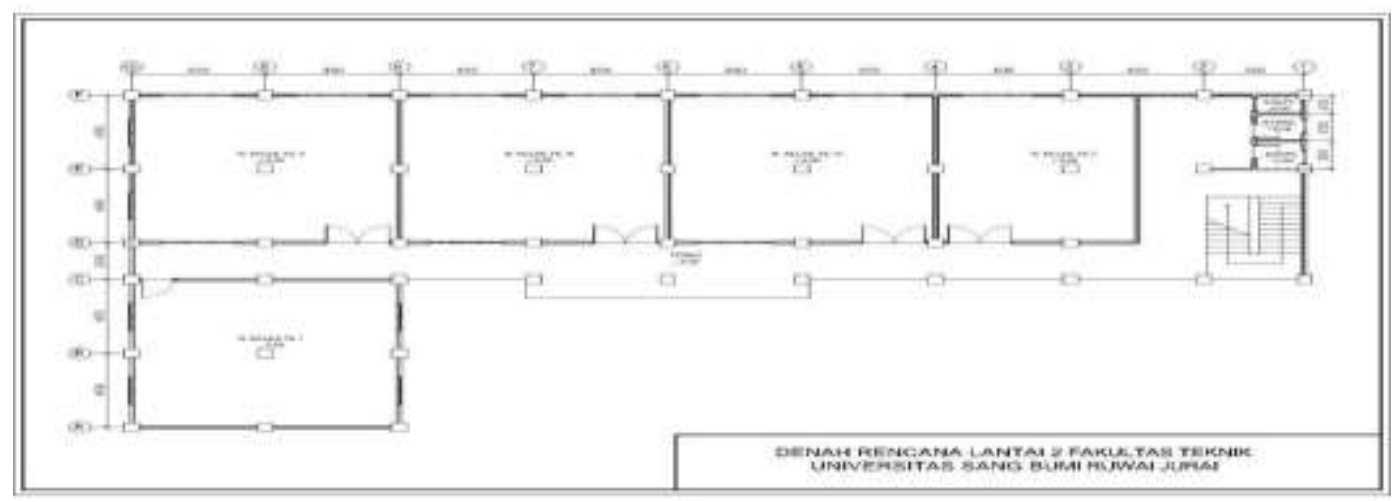

Gambar 2. Denah Lantai 1 Fakultas Teknik Universitas Sang Bumi Ruwa Jurai 


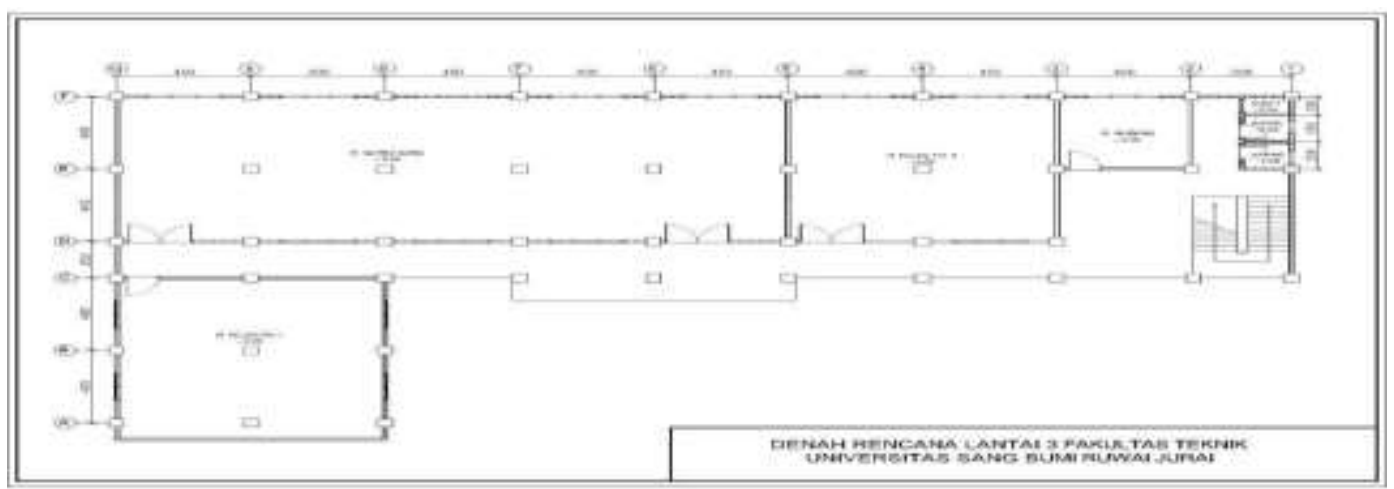

Gambar 3. Denah Lantai 2 Fakultas Teknik Universitas Sang Bumi Ruwa Jurai

\section{Desain Awal Struktur}

\section{Perencanaan Dimensi Balok}

\begin{tabular}{cccc} 
& \multicolumn{3}{c}{ Tabel 1. Dimensi Balok } \\
\cline { 1 - 1 } No & Notasi & b xh(cm) & Keterangan \\
\hline 1 & B1 & $35 \times 60$ & Balok Induk \\
2 & B2 & $30 \times 50$ & BalokAnak \\
\hline
\end{tabular}

\section{Perencanaan Dimensi Plat}

Dari hasil perhitungan tersebut digunakan tebal pelat lantai $(\mathrm{h})=120 \mathrm{~mm}$ dan tebal pelat atap $(\mathrm{h})=10 \mathrm{~mm}$.

\section{Perencanaan Dimensi Kolom}

\begin{tabular}{ccc} 
& \multicolumn{2}{c}{ Tabel 2.. Dimensi Kolom } \\
\hline Lantai & Notasi & Dimensi $(\mathbf{c m})$ \\
\hline 1 & K1 & $50 \times 50$ \\
2 & K1 & $50 \times 50$ \\
3 & K2 & $40 \times 40$
\end{tabular}

\section{Pemodelan Struktur Gedung pada Program ETABS Versi 18.1.1}

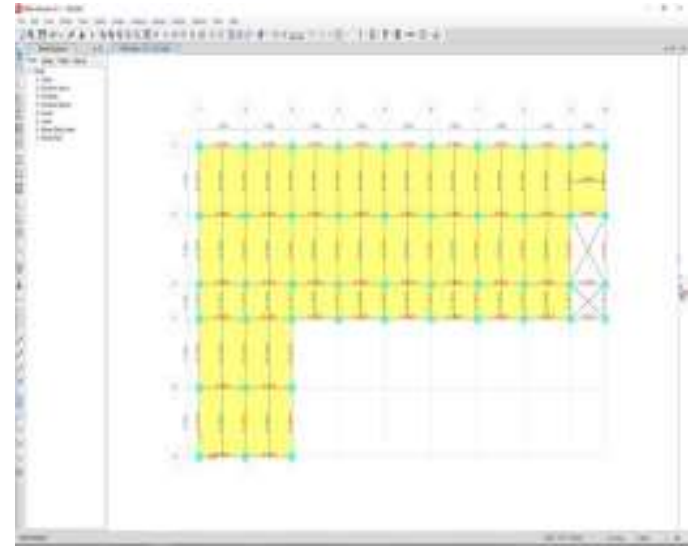

Gambar 4. Pemodelan Denah Lantai 1 dan 2

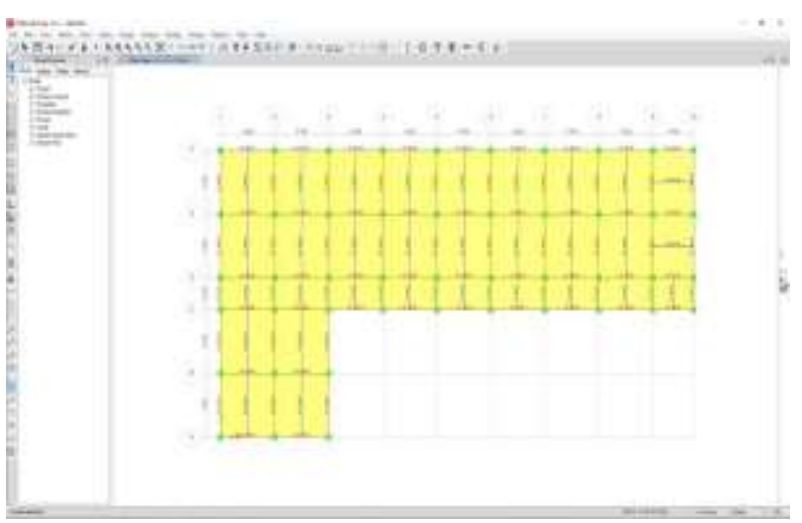

Gambar 5. Pemodelan Denah Atap 

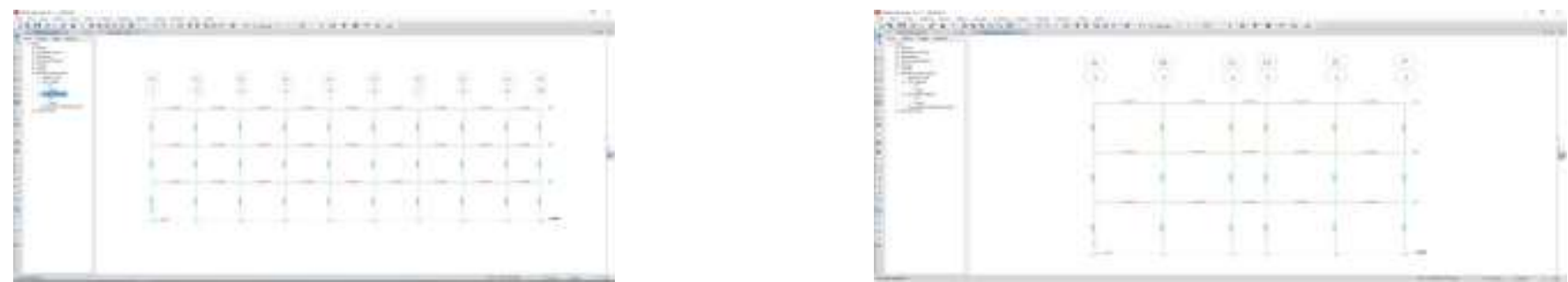

Gambar 6.7. Pemodelan Potongan Struktur Gedung pada Frame 1D s/d 10D

Gambar 8. Pemodelan Potongan Struktur Gedung pada Frame 10A s/d 10

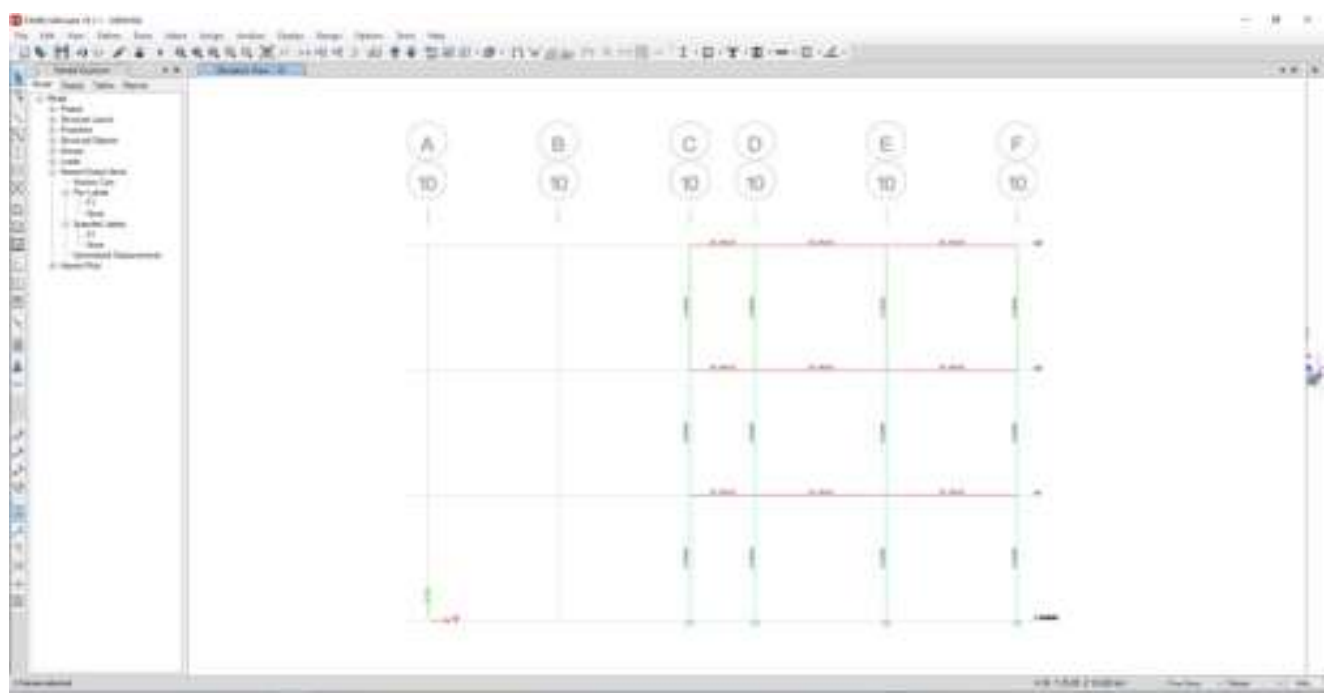

\section{Pembebanan Model Struktur}

a. Beban Mati (Dead Load)

- Beban mati (QD) pada pelat lantai 2 dan $3=184 \mathrm{Kg} / \mathrm{m}^{2}=1,803 \mathrm{Kn} / \mathrm{m}^{2}$

- Beban mati tambahan (QD) pada pelat atap $=89 \mathrm{Kg} / \mathrm{m}^{2}=0.8722 \mathrm{Kn} / \mathrm{m}^{2}$ Untuk beban mati yang berasal dari dinding pasangan batu bata dihitung sebagai berikut $=(4-0,4) \times 250=900 \mathrm{Kg} / \mathrm{m}^{2}=8.821 \mathrm{KN} / \mathrm{m}^{2}$

b. Beban Hidup (Live Load)

- Beban hidup pada lantai gedung perkantoran diambil sebesar $2.50 \mathrm{Kn} / \mathrm{m}^{2}$,

- Untuk atap diambil sebesar $1 \mathrm{Kn} / \mathrm{m}^{2}$

- Dalam arah X struktur gedung ini direncanakan sebagai sistem rangka pemikul momen menengah beton $(\mathrm{SRPMM})=5,5$

- Arah Y struktur gedung ini direncanakan sebagai sistem interaksi rangka pemikul momen menengah beton bertulang dan dinding geser beton bertulang $($ Sistem Ganda) $=6,5$.

c. Kombinasi Pembebanan

- Comb $1=1,4$ DEAD

- Comb $2=1,2 \mathrm{DEAD}+1,6 \mathrm{LIVE}+0,5 \mathrm{R}$

- Comb $3=1,2 \mathrm{DEAD}+1,6 \mathrm{LIVE}+0,5 \mathrm{~W}$

- Comb $4=1,2 \mathrm{DEAD}+1,0 \mathrm{WX}+\mathrm{L}+0,5 \mathrm{R}$

- Comb $5=1,2 \mathrm{DEAD}+1,0 \mathrm{WY}+\mathrm{L}+0,5 \mathrm{R}$

- Comb 6= 1,2 DEAD + LIVE + 0,3 RSX + RSY 
- $\quad$ Comb 7=1,2 DEAD + LIVE + 0,3 RSY+ RSX

- Comb $8=0,9$ DEAD + RSX

- $\operatorname{Comb} 9=0,9 \mathrm{DEAD}+\mathrm{RSY}$

\section{Analisis Struktur}

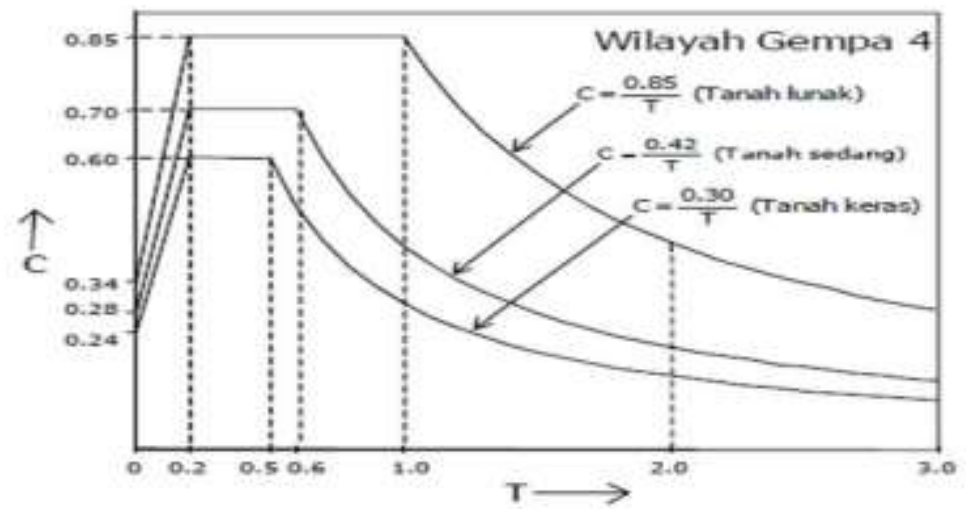

Gambar 10.Grafik Fungsi Spektrum Respons Wilayah Gempa 4

Massa total gedung pada arah X (Wtx) sebesar $1834833.08 \mathrm{~kg}$ dan massa total gedung pada arah Y (Wty) sebesar $1834833.08 \mathrm{~kg}$.

\section{Pemeriksaan Kekakuan Struktur}

a. Kinerja batas layan $(\Delta s)$

$\Delta \mathrm{s}=(0,03 / \mathrm{R}) \times \mathrm{hi} \leq 30 \mathrm{~mm}$

Dimana hi adalah tinggi tingkat yang ditinjau. Sehingga simpangan antar tingkat untuk masing-masing arah tidak boleh lebih besar dari:

- Pada arah X $\Delta \mathrm{sx}=(0,03 / 5,5) \times 4000=21,818 \leq 30 \mathrm{~mm}$

- Pada arah Y $\Delta$ sy $=(0,03 / 6,5) \times 4000=18,462 \leq 30 \mathrm{~mm}$

b. Kinerja batas ultimit $(\Delta \mathrm{M})$

$$
\begin{array}{ll}
\Delta \mathrm{s}=\zeta \mathrm{x} \Delta \mathrm{s}=0,02 \times 4000=80 \mathrm{~mm} \\
\Delta \mathrm{sx} & =45,8-44,17=1,630 \mathrm{~mm} \\
\Delta \mathrm{mx} & =1,630 \times 0,7 \times 5,5=6,276 \mathrm{~mm} \\
\Delta \mathrm{sy} & =39,89-36,21==3,68 \mathrm{~mm} \\
\Delta \mathrm{mx} & =3,68 \times 0,7 \times 6,5==16,744 \mathrm{~mm}
\end{array}
$$

7. Perhitungan Struktur dengan Program ETABS Versi 18.1.1

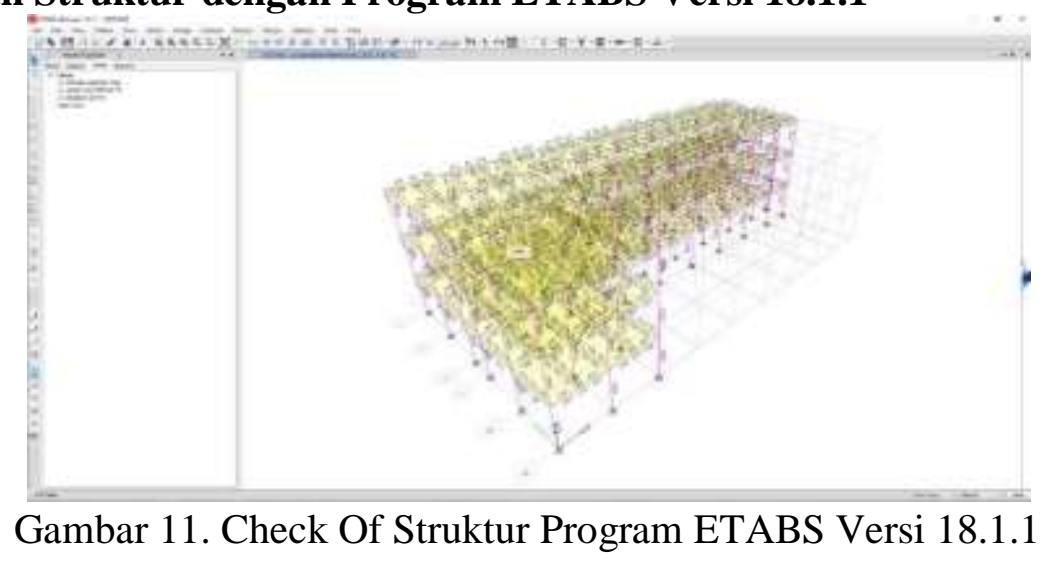




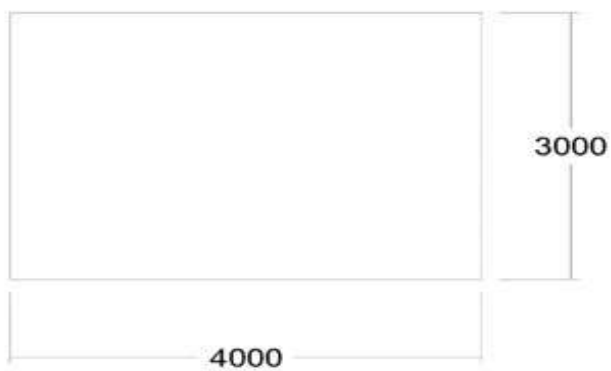

Gambar 12.Type Plat Atap

a. Data perhitungan plat atap

Mutu beton yang digunakan f'c

Mutu tulangan yang digunakan fy

$=25 \mathrm{Mpa}$

Tebal plat atap

$=240 \mathrm{Mpa}$

Berat jenis beton bertulang

Panjang plat arah $\mathrm{x}(\mathrm{Lx})$

$=100 \mathrm{~mm}$

Panjang plat arah y (Ly)

$=2400 \mathrm{~kg} / \mathrm{m}^{3}$

$=4 \mathrm{~m}$

$=3 \mathrm{~m}$

b. Pembebanan plat atap

Beban mati $(\mathrm{Qd})=329 \mathrm{Kg} / \mathrm{m}^{2}=3.224 \mathrm{Kn} / \mathrm{m}^{2}$

Beban hidup (LL) $=1 \mathrm{Kn} / \mathrm{m}^{2}$

Jumlah beban perlu $(\mathrm{Qu})=554.8 \mathrm{Kg} / \mathrm{m}^{2}=5.437 \mathrm{Kn} / \mathrm{m}^{2}$

c. Perhitungan penulangan plat atap

Mlx $=299.592 \mathrm{Kgm}$

Mly $\quad=72.401 \mathrm{Kgm}$

Mtx $=411.939 \mathrm{Kgm}$

Mty $=259.64 \mathrm{Kgm}$

Diameter tulangan yạng digunakan $\emptyset 10 \mathrm{~mm}$

Gambar 13.Potongan Pelat Atap

Penulangan sejajar sisi pendek

Penulangan Lapangan, dipasang tulangan $\varnothing 10-175\left(\right.$ As $\left.=448.5 \mathrm{~mm}^{2}\right)$

Penulangan Tumpuan, dipasang tulangan $\varnothing 10-175\left(\right.$ As $\left.=448.5 \mathrm{~mm}^{2}\right)$

Penulangan sejajar sisi panjang (ly)

Penulangan lapangan, dipasang tulangan $\varnothing 10-200\left(\right.$ As $\left.=392.5 \mathrm{~mm}^{2}\right)$

Penulangan tumpuan, dipasang tulangan $\varnothing 10-200\left(\mathrm{As}=392.5 \mathrm{~mm}^{2}\right)$

\section{Analisa Perhitungan Pelat Lantai Secara Manual}




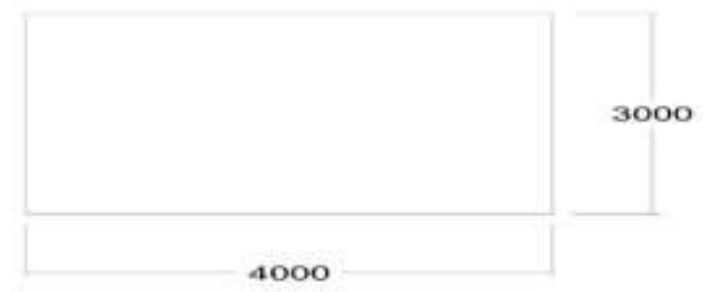

Gambar 14.Type Plat Lantai

1. Data perhitungan plat Lantai
a. Mutu beton yang digunakan fc'

$$
\begin{aligned}
& =25 \mathrm{Mpa} \mathrm{b} . \\
& 240 \mathrm{Mpac} . \\
& 120 \mathrm{~mm} \\
& =2400 \mathrm{~kg} / \mathrm{m}^{3} \\
& =3 \mathrm{~m}
\end{aligned}
$$$$
\text { Mutu tulangan yang digunakan fy } \quad=240 \mathrm{Mpa} \text {. }
$$$$
\text { Tebal plat atap }
$$$$
\text { d. Berat jenis beton bertulang }
$$$$
=120 \mathrm{~mm}
$$$$
\text { e. Panjang plat arah } \mathrm{x}(\mathrm{Lx})
$$$$
\text { f. Panjang plat arah y (Ly) }
$$$$
=4 \mathrm{~m}
$$

2. Pembebanan plat Lantai
a. Beban mati $(\mathrm{Qd})$
$=472 \mathrm{Kg} / \mathrm{m}^{2}$
$=4.62 \mathrm{Kn} / \mathrm{m}^{2}$
b. Beban hidup (LL)
$=2.5 \mathrm{Kn} / \mathrm{m}^{2}$
c. Jumlah beban perlu $(\mathrm{Qu})=966,400 \mathrm{Kg} / \mathrm{m}^{2}=9.470 \mathrm{Kn} / \mathrm{m}^{2}$

3. Perhitungan penulangan plat atap

$$
\begin{array}{ll}
\text { X1 } & =60 \quad \text { X2 }=14,5 \\
\text { X3 } & =82,5 \quad \text { X4 }=52 \\
\text { Mlx } & =521,856 \mathrm{Kgm} \\
\text { Mly } & =126,1152 \mathrm{Kgm} \\
\text { Mtx } & =-717,552 \mathrm{Kgm} \\
\text { Mty } & =-452,2752 \mathrm{Kgm}
\end{array}
$$

Diameter tulangan yang digunakan $\varnothing 10 \mathrm{~mm}$.

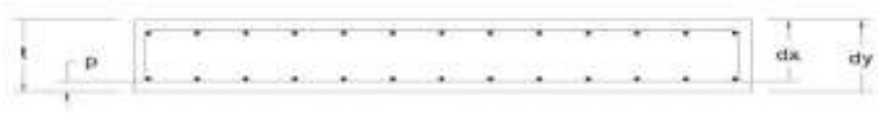

Gambar 15. Potongan Plat Lantai

Penulangan sejajar sisi pendek (lx)

Penulangan Lapangan, dipasang tulangan $\varnothing 10-125\left(\right.$ As $\left.=625 \mathrm{~mm}^{2}\right)$

Penulangan Tumpuan, dipasang tulangan $\emptyset 10-125\left(\right.$ As $\left.=625 \mathrm{~mm}^{2}\right)$

enulangan sejajar sisi panjang (ly)

Penulangan lapangan, dipasang tulangan $\varnothing 10-150\left(\right.$ As $\left.=523.33 \mathrm{~mm}^{2}\right)$

Penulangan tumpuan, dipasang tulangan $\varnothing 10-150\left(\right.$ As $\left.=523.33 \mathrm{~mm}^{2}\right) \backslash$

\section{Analisa Perhitungan Balok B2}

\section{Penulangan Tumpuan Balok B2}

Dari hasil perhitungan yang dimodelkan oleh program ETABSVersi 18.1.1, output untuk luas tulangan tumpuan yaitu:

Luas tulangan As (Top Rebar Area) $=1125 \mathrm{~mm}^{2}$ Direncanakan 6 D $16=1206 \mathrm{~mm}^{2}$ As rencana $=1206 \mathrm{~mm}^{2}>$ As perlu $=1125 \mathrm{~mm}^{2}, \ldots \ldots \ldots$. OK Luas tulangan As' (Bottom Rebar Area) $=955 \mathrm{~mm}^{2}$ Direncanakan 5 D $16=1005 \mathrm{~mm}^{2}$

As rencana $=1005 \mathrm{~mm}^{2}>$ As perlu $=955 \mathrm{~mm}^{2}$ .OK

\section{Penulangan Geser}


a. Tulangan geser daerah tumpuan

Digunakan $\Phi 10-150 \mathrm{~mm}$

$=2 \times 1 / 4 \pi \mathrm{d}^{2} \times 1000 / 150$

$=2 \times 1 / 4 \pi 10^{2} \times 1000 / 150=1040 \mathrm{~mm}^{2}$

Sehingga luas tulangan per meter panjang $=1040 / 1000=1,040 \mathrm{~mm}^{2}$

Kontrol keamanan $=1,04 \mathrm{~mm}^{2}>0,000 \mathrm{~mm}^{2}$, sengkang aman

b. Tulangan geser daerah lapangan

Digunakan $\varnothing 10-150 \mathrm{~mm}$

$=2 \times 1 / 4 \pi \mathrm{d}^{2} \times 1000 / 150$

$=2 \times 1 / 4 \pi 10^{2} \times 1000 / 150=1047 \mathrm{~mm}^{2}$

Sehingga luas tulangan per meter Panjang $=1047 / 1000=1,047 \mathrm{~mm}^{2}$

Kontrol keamanan $=1,047 \mathrm{~mm}^{2}>0,000 \mathrm{~mm}^{2}$, sengkang aman

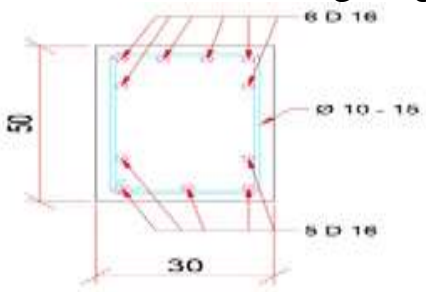

Gambar 16.Penulangan BalokB2

\section{Analisa Perhitungan Balok B1}

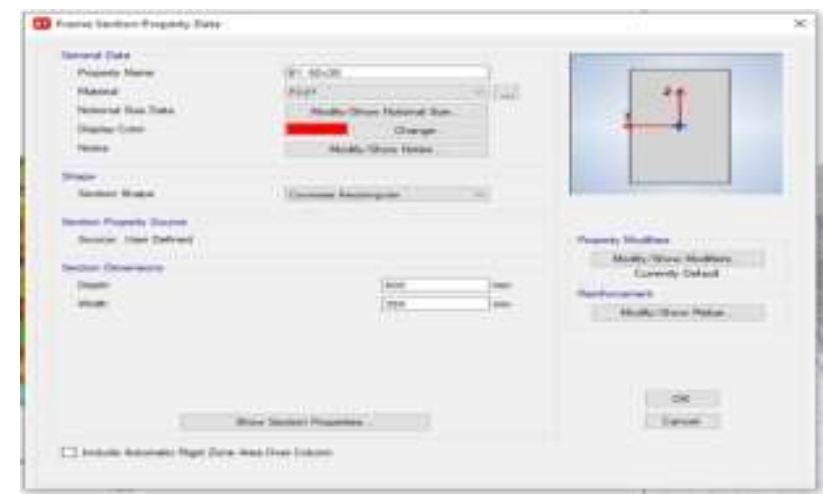

Gambar 17. Tulangan Balok B1 pada Program ETABS

\section{Penulangan Tumpuan Balok Induk B1}

Dari hasil perhitungan yang dimodelkan oleh program ETABS, output untuk luas tulangan tumpuan yaitu:

Luas tulangan As (Top Rebar Area) $=2100 \mathrm{~mm}^{2}$

Direncanakan 8 D $19=2268 \mathrm{~mm}^{2}$

As rencana $=2268 \mathrm{~mm}^{2}>$ As perlu $=2100 \mathrm{~mm}^{2}$, .OK

Luas tulangan As' (Bottom Rebar Area) $=1200 \mathrm{~mm}^{2}$

Direncanakan 5 D $19=1418 \mathrm{~mm}^{2}$ (tabel luas tulangan balok,kolom) As

rencana $=1418 \mathrm{~mm}^{2}>$ As perlu $=1200 \mathrm{~mm}^{2}$ .OK

\section{Penulangan Geser}

$$
\begin{aligned}
& \mathrm{Vu}=13862.430 \mathrm{~N} \\
& \text { 2. } \mathrm{Vc}=\frac{\sqrt{27}}{6} \cdot 300.550=142894 \mathrm{~N} \\
& \text { n. }{ }^{1} \pi \cdot 22^{1} \cdot \pi \cdot 10^{2} .1000
\end{aligned}
$$


Seminar Nasional Penelitian dan Pengabdian kepada Masyarakat Universitas Sang Bumi Ruwa Jurai Tahun 2020

$$
\mathrm{S}=\frac{4}{\mathrm{Av}}=\frac{4}{291.66}=538 \mathrm{~mm}^{2}
$$

Dipakai tulangan geser $\varnothing 10-150$

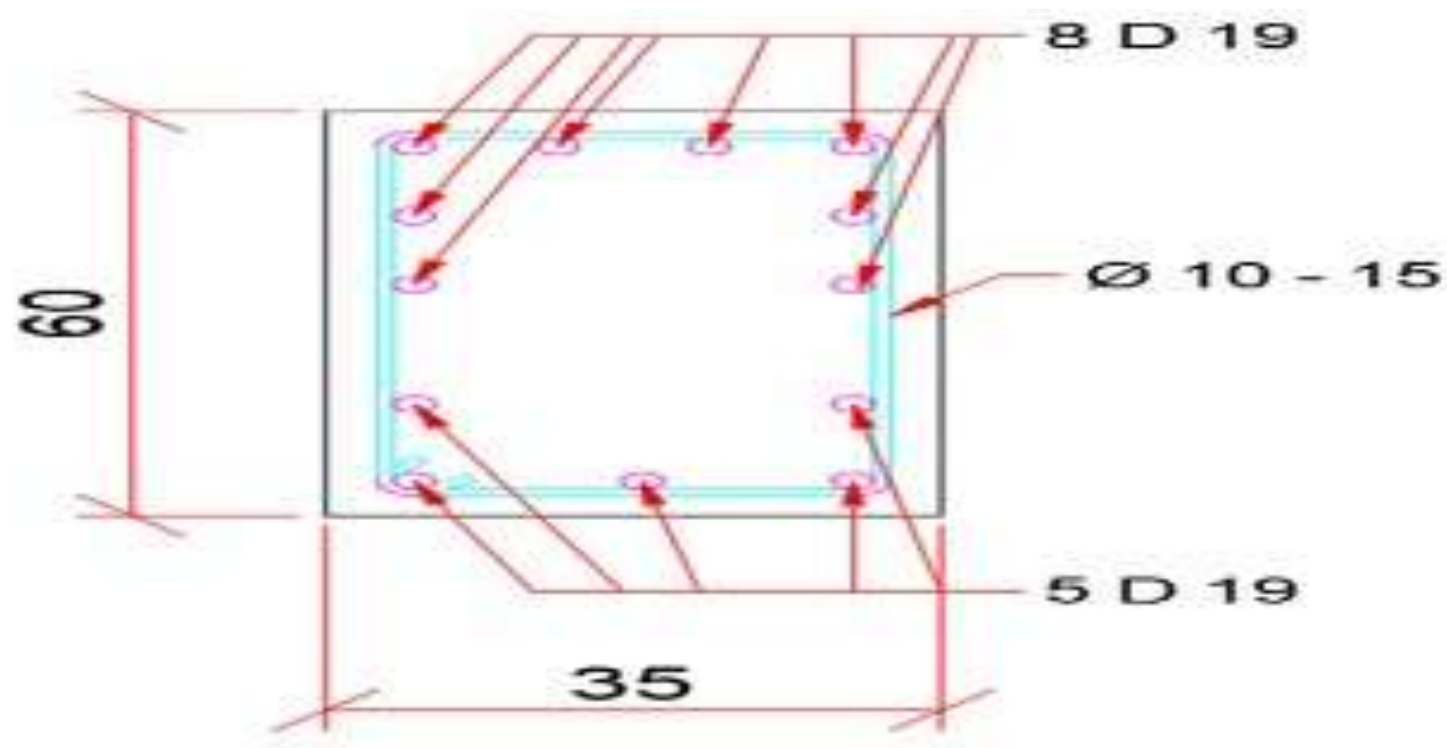

Gambar 18.Detail Penulangan Balok B1 


\section{Analisa Perhitungan Kolom K1}

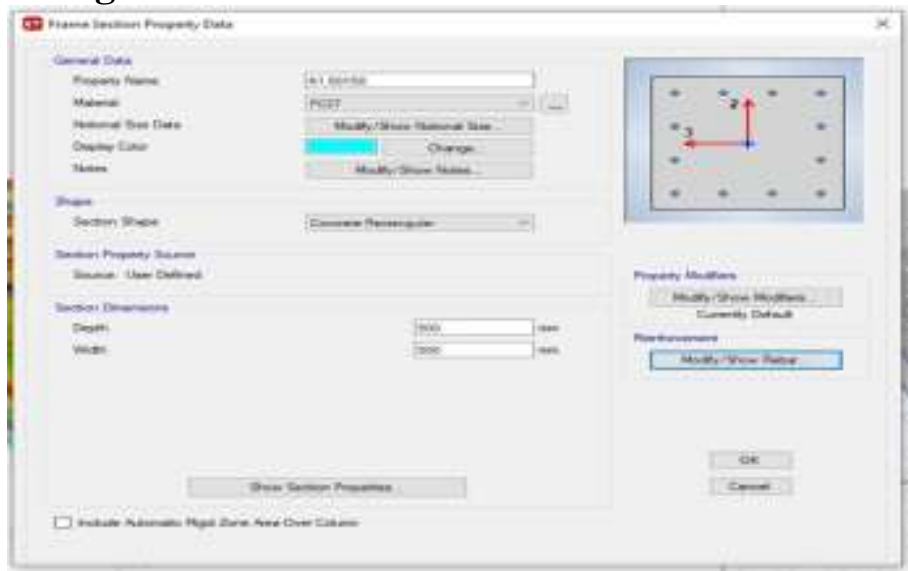

Gambar 19. Tulangan Kolom K1 pada Program ETABS Versi 18.1.1

\section{Penulangan Lentur Kolom}

Direncanakan12 D $19=3402 \mathrm{~mm}^{2}$

As rencana $=3402 \mathrm{~mm}^{2}>$ As perlu $=2500 \mathrm{~mm}^{2}$ .Ok

\section{Penulangan Geser Kolom}

Pakai tulangan geser $\varnothing 10-150 \mathrm{~mm}$.

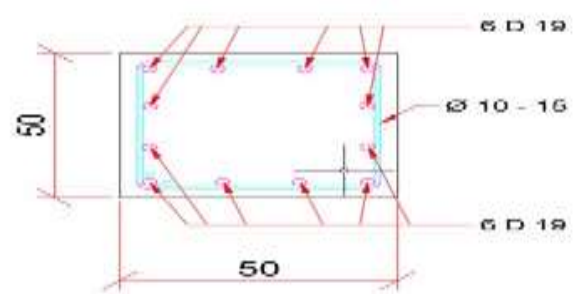

Gambar 20. Detail Penulangan Kolom K1

\section{Analisa Perhitungan Kolom K2}

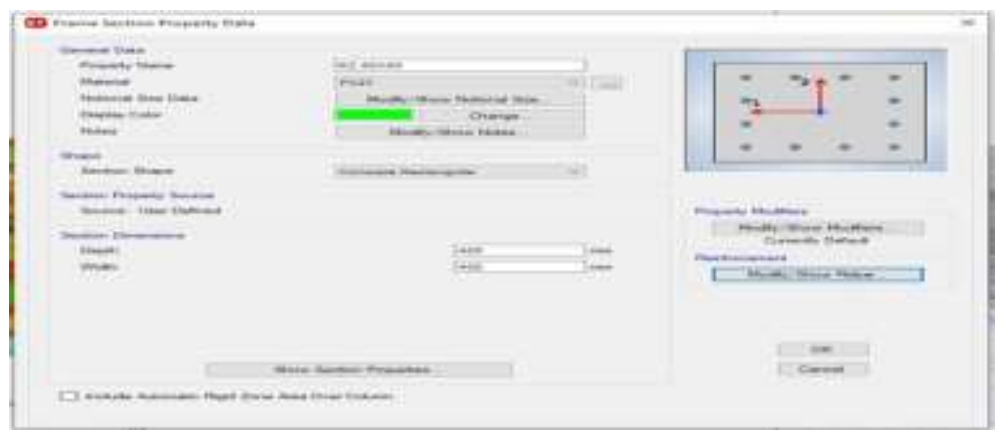

Gambar 21. Tulangan Kolom K2 pada Program ETABS Versi 18.1.1

\section{Penulangan Lentur Kolom}

Direncanakan 12 D $16=2400 \mathrm{~mm}^{2}$

As rencana $=2400 \mathrm{~mm}^{2}>$ As perlu $=2190 \mathrm{~mm}^{2}, \ldots \ldots . . \mathrm{Ok}$

\section{Penulangan Geser Kolom}

Pakai tulangan geser $\varnothing 10-150 \mathrm{~mm}$. 


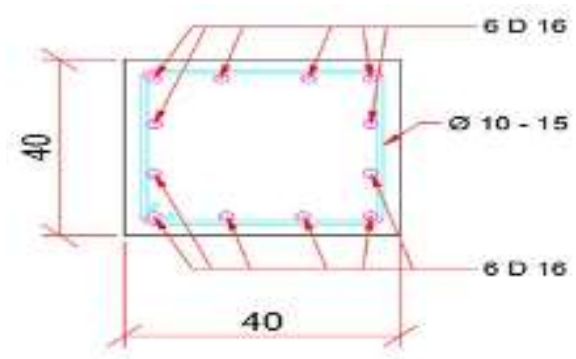

Gambar 22. Detail Penulangan Kolom K2

\section{KESIMPULAN}

Berdasarkan hasil perhitungan permodelan penelitian struktur yang dilakukan, maka dapat disimpulkan bahwa:

1. Rancangan permodelan yang dilakukan dalam penelitian ini, selain menggunakan program lumion tapi juga menerapkan estetika, tata letak dan berbagai faktor teknis masukan yang dapat digunakan dan dipraktekan dalam pelaksanaannya nanti.

2. Analisa struktur bangunan gedung khususnya beton bertulang meliputi, balok, kolom, dak atap dan plat lantai dihitung menggunakan program ETABS Versi 18.1.1. Perhitungan struktur gedung ini menggunakan mutu beton $\mathrm{fc} \mathrm{c}^{\prime}=27 \mathrm{Mpa}$ dan mutu baja fy $=400 \mathrm{Mpa}$.

3. Dari hasil analisa struktur dengan program ETABS, Dengan hasil perhitungan untuk menentukan hasil dimensi tulangan sebagai berikut :

a. Plat atap

1) Tulangan arah $x$

Tulangan tumpuan arah $\mathrm{x}=\varnothing 10-175\left(\mathrm{As}=448.5 \mathrm{~mm}^{2}\right)$ Tulangan

Lapangan arah $\mathrm{x}=\varnothing 10-175\left(\mathrm{As}=448.5 \mathrm{~mm}^{2}\right)$

2) Tulangan arah $y$

Tulangan tumpuan arah $\mathrm{y}=\varnothing 10-200\left(\mathrm{As}=392.5 \mathrm{~mm}^{2}\right)$ Tulangan lapangan arah $\mathrm{y}=\varnothing 10-200\left(\mathrm{As}=392.5 \mathrm{~mm}^{2}\right)$

b. Plat lantai

1) Tulangan arah $x$

Tulangan tumpuan arah $\mathrm{x}=\varnothing 10-125\left(\mathrm{As}=625 \mathrm{~mm}^{2}\right)$ Tulangan lapangan $\operatorname{arah} \mathrm{x}=\emptyset 10-125\left(\mathrm{As}=625 \mathrm{~mm}^{2}\right)$

2) Tulangan arah $y$

Tulangan tumpuan arah $\mathrm{y}=\varnothing 10-150\left(\mathrm{As}=523.33 \mathrm{~mm}^{2}\right)$ Tulangan lapangan arah $\mathrm{y}=\varnothing 10-150\left(\mathrm{As}=523.33 \mathrm{~mm}^{2}\right)$

c. Perhitungan balok dan kolom yang dihitung menggunakan program ETABS mendapatkan hasil sebagai berikut:

1) Balok Induk / B1 dengan dimensi $600 \mathrm{~mm} \times 300 \mathrm{~mm}$ pada daerah tumpuan As = 8 D 19 mm dan As' = 5 D 19 mm, dengan jarak sengkang $\varnothing 10$ $-150 \mathrm{~m}$.

2) Balok Anak / B2 dengan dimensi $500 \mathrm{~mm}$ x $300 \mathrm{~mm}$ pada daerah tumpuan As = 6 D $16 \mathrm{~mm}$ dan As' = 5 D $16 \mathrm{~mm}$, dengan jarak sengkang $\varnothing 10$ $-150 \mathrm{~mm}$

3) Kolom K1 dengan dimensi $500 \mathrm{~mm} \times 500 \mathrm{~mm}$ digunakan tulangan $12 \mathrm{D} 19$ dengan jarak sengkang $\varnothing 10-150 \mathrm{~mm}$.

4) Kolom $\mathrm{K} 2$ dengan dimensi $400 \mathrm{~mm} \times 400 \mathrm{~mm}$ digunakan tulangan 12 D 16 dengan jarak sengkang $\varnothing 10-150 \mathrm{~mm}$. 
d. Dari hasil pemodelan struktur dengan program ETABS Versi 18.1.1, struktur gedung yang direncanakan masuk dalam katagori aman, hal ini terlihat jelas bahwa tidak ada struktur bangunan utama yang mengalami beban berlebih (Overstress) dalam arti struktur gedung mampu menahan beban yang bekerja pada bangunan tersebut.

\section{DAFTAR PUSTAKA}

Badan Standardisasi Nasional. (2012). Standar Nasional Indonesia :Tata Cara Perencanaan Ketahanan Gempa untuk Struktur Bangunan Gedung dan Non Gedung, SNI 03-17262012.

Badan Standardisasi Nasional. (2002). Standar Nasional Indonesia :Tata Cara Perhitungan Struktur Beton untuk Bangunan Gedung SNI 03-2847-2002.

Masagala Algazt Arsyad, Faqih Ma'Arif. (2016). "Perencanaan Struktur Beton Bertulang Tahan Gempa Berlantai 4 : Studi Kasus Gedung Baru Kampus I Universitas Teknologi Yogyakarta (The Planning of Four-Story Anti-Earthquake Reinforced Concrete Structure: Case Study of The New Building in Campus One of Universitas Teknologi Yogyakarta)”. Jurnal Ilmiah Semesta Teknika. Vol.19, No.1,20-89.

Monica Aulia. (2014). "Tinjauan Perhitungan Struktur Gedung The 18 Office Park Jakarta”.Jurnal Teknik Sipil dan Lingkungan. Vol.2.No.3,September2014.

Nandani Putra Rizki, Andina Prima Putra. "Perencanaan Struktur Gedung Bertingkat Studi Kasus :Sekolah Tahfidz Banjir KanalTimur”.Jurnal Kajian Teknik Sipil. Vol.2 No.2

Pratama Adhitya, Januar Oni Bagus Amandani, HardiWibowo, Parang Sabdono. (2018). "Perencanaan Struktur Gedung Kuliah Fakultas Ekonomi Unnes Semarang”.Jurnal KaryaTeknikSipil. Volume 7, Nomor 1, Tahun 2018, Halaman 176-188. 